\title{
F. Matthias Alexander and Mabel Elsworth Todd: Proximities, practices and the psycho- physical
}

Michael Huxley, De Montfort University

\begin{abstract}
Proximities in the work of F. Matthias Alexander and Mabel Elsworth Todd are examined for the first time. There are close geographical proximities in their location and to those in their respective circles during the period 1914-1937. Both Alexander and Todd drew on ideas prevalent at the turn of the twentieth century. There are historical proximities based around the intellectual hub of New York City, notably to the philosopher John Dewey, the historian James Harvey Robinson and the pioneer dance educationalist Margaret H'Doubler. Alexander's and Todd's ideas and practices are considered in their time from a starting point of the idea of the 'psycho-physical', a term used by these practitioners in their writings. They both used it to try and speak about the self in a new way, and what they proposed had major ramifications. The article concludes by suggesting that we might reconsider how we think of dancers and dance students in the light of this historical reconsideration of Alexander's and Todd's ideas.
\end{abstract}

\section{Keywords}

dance

education

history

physical culture

psycho-physical 
somatic

\section{Introduction}

In the very first issue of the Journal of Dance and Somatic Practices in 2009, Martha Eddy outlined a history of somatic practices and dance. She acknowledges the fact that the terms 'somatics' and 'somatic education' are relatively recent ones, following Hanna and others (Eddy 2009: 6-7). She then traces the development of somatic education back to the beginning of the twentieth century and identifies eight of what she refers to as 'somatic pioneers':

Based on common lore, oral tradition, and written treatises such as those edited by Don Hanlon Johnson (1995), I have identified F. M. Alexander, Moshe Feldenkrais, Mabel Todd, Irmgard Bartenieff, Charlotte Selver, Milton Trager, Gerda Alexander, and Ida Rolf as 'the somatic pioneers'. (Eddy 2009: 12)

Although she does not say so explicitly, within her definition, Todd and Alexander were the first of these. They were born, began practising and were published before the others. A simple chronological listing makes the point and emphasizes the distinctive nineteenth-century location of both Alexander's and Todd's early years:

F. Matthias Alexander

Mabel Elsworth Todd

Ida Rolf

Irmgard Bartenieff

Charlotte Selver
(1869-1955)

(1874-1956)

(1896-1979)

(1900-1981)

(1901-2003) 
Moshe Feldenkrais

Gerda Alexander

Milton Trager
(1904-1984)

(1908-1994)

(1908-1997)

Alexander developed his technique in Tasmania, Australia, England and the United States. He opened a practice in Melbourne in 1896, in London in 1904 and in New York in 1914. He published his first significant articles in London in 1906 and his first books in 1910, 1912 and 1918. ${ }^{1}$ Todd opened her first studio in Boston in 1914, and a second studio in New York in 1920 with, her first published articles in 1920 and $1921 .^{2}$ In other words, their practices and writing were well established before any of the other 'pioneers' began their own work. Eddy's account, which attributes 'pioneer' status to them, is strikingly similar to the traditional genealogical accounts of modern dance following Maynard (1964), who retrospectively identified the 'four pioneers' - Martha Graham, Doris Humphrey, Charles Weidman and Hanya Holm, dancers who came to prominence in the 1920s and 1930s, the same period that is being discussed here with respect to Alexander's and Todd's work. My analysis is not designed to suggest any 'genealogical' link between Alexander and Todd and later practitioners.

[Figures 1 and 2 to go here side by side]

Alexander and Todd have both been written about separately as historical figures. Recently, a number of authors including Johnson (1995), Fitt ([1988] 1996), Bales and Nettl-Fiol (2008) and Eddy (2009) have written about them in a way that suggests that their approaches lend themselves to being categorized together. However, there is no extant detailed researched comparison. This article reconsiders the historical situation of Alexander and Todd in the period 
1910-1937, and looks at proximities in the development of their practice for the very first time. I will contend that there was greater proximity between their work in its time than is acknowledged in the literature. I will show this proximity in terms of geographical location, intellectual networks, context and the way their ideas were taken up by their intellectual contemporaries. They were pioneers in the sense that both of them addressed the question of personal change in an embodied way without recourse to exercise regimes.

For the purpose of this article, I will focus on one aspect of Alexander's and Todd's work, primarily through analysis of their publications. This is that part of their work that tries to delineate how they conceive of the 'self', as Alexander's book had it in 1932, or 'the thinking body', as Todd's most famous work had it in 1937. A term they both employed is 'psychophysical'. In both cases, there are many other concepts intimately and inextricably tied up with psycho-physical, not least habit, sensory appreciation and inhibition (which both employ), use, ${ }^{3}$ which is particular to Alexander and imagery, which is particular to Todd. However, whilst acknowledging their importance, within the constraints of a short article, I am only going to consider the psycho-physical. A detailed examination of Alexander's and Todd's techniques, to follow in a further article, will also show that there were considerable differences in practice and underlying theory. ${ }^{4}$ The term 'psycho-physical' is especially interesting because it enters the vocabularies of science, philosophy and physical culture in the late nineteenth century at a time when Alexander's and Todd's early ideas were developing. From a twenty-first-century perspective I suggest that a closer examination of the idea of the psycho-physical in its original historical setting can help illuminate discussion of conceptions of the person as dancer, not least in terms of current usage of psycho-physical, body-mind and indeed somatics. 


\section{Geographical and historical proximities}

I begin with the historical situation. Alexander and Todd practiced their respective methods (later techniques) and began to be published over a decade earlier than any of the other six 'pioneers' identified by Eddy. Significantly, they both taught in New York and Boston from 1914 to 1924, a crucial time in the development of modern dance and dance education in the United States . For the historical record on Alexander, I have drawn on accounts by Jones ([1976] 1997), Evans (2001) and Staring (2005), in particular, for Todd, on Matt (1973, 1993, 2011). In addition, my own research has included, for instance, a close reading of primary and secondary works on and by their contemporaries, including Dewey, H'Doubler, Robinson and Williams, searches of US census returns; and shipping lists, maps and newspapers of the period. The main historical accounts of Alexander make no significant reference to Todd; Matt's accounts of Todd make passing reference to Alexander. None of the historical writers on Todd or Alexander have compared one with the other.

The historical proximities between Alexander and Todd are far greater than usually acknowledged. However, they did not start out very close geographically. They were born some 10,000 miles apart: he in 1869 in Wynyard, Tasmania,: she in 1874 in Syracuse, New York. Alexander developed a method of respiratory re-education, emigrated from Australia to London in 1904, and published the first of many articles in England on this method in 1906. Todd graduated from the Boston Conservatory of Elocution, Oratory and Dramatic Art in 1909, and began teaching in Boston, MA in 1910. It is notable that both have a background in oratory. Alexander was well known as a professional reciter in Tasmania and Australia in the late 
nineteenth century. It was the loss of his voice and threat to his professional career that led him to discover ${ }^{5}$ his technique, as documented in his 1932 book. Todd's training at the Boston Conservatory was in the employment of the voice in speaking and recitation, following Charles Wesley Emerson's principles of oratory (c. 1891).

The year 1910 saw the publication of Alexander's first book, Man's Supreme Inheritance, in London where he had established a practice teaching A New Method of Respiratory Vocal ReEducation (1906). Todd opened her Studio for Natural Posture to teach better breathing and voice production in Boston in 1914, where she lived at 99 Commonwealth Avenue. In September of that year Alexander left England for the United States. For the next decade he ran a practice in New York and London, travelling back and forth across the Atlantic by boat. His brother A. R. Alexander joined him and the two of them extended the practice to Boston in 1920. They continued to teach in the two cities until 1924 before returning to London. The Boston practice reopened in 1933. Alexander's second edition of Man's Supreme Inheritance (1918) and his Constructive Conscious Control of the Individual (1923) were published during this time. He outlined how he came to develop his technique in his 1932 book The Use of the Self. Todd's The Balancing of Forces in the Human Being was published in 1929 and The Thinking Body in 1937.

In 1920 Alexander was living in New York on the corner of Madison Avenue and 59th

Street, a short walk from his New York practice based since 1914, at the Essex Hotel at 56th and Madison. In the same year Todd opened a studio three blocks away at 160 Central Park South.

[Figure 3 to go here] 
When the Alexander brothers began teaching in Boston in the same year, 1920, they had a practice at the house of Dr Codman of the Massachusetts General Hospital on Beacon Street, a short way away from Commonwealth Avenue, and also taught at Brimmer Street. In 1920, Todd had her first paper published in the Boston Medical and Surgical Journal (now the New England Journal of Medicine), mentored by Dr E. G. Brackett, an established contributor from the Orthopedic Department of the Massachusetts General Hospital, not far from where both Todd and Alexander taught.

I have made a point of highlighting Alexander and Todd's geographical proximity in Boston and New York. In both New York and Boston they had practices in the same neighbourhood. My suggestion is that they might have drawn on clients from a similar social circle. It is widely acknowledged, by Jones ([1976] 1997) and Evans (2001) in particular, that Alexander had clients who were wealthy professionals. The location suggests that Todd might have had a similar client base. I am now going to look at one particular group of professionals by examining how they moved in similar academic circles in New York City. Alexander began teaching members of the faculty at Columbia University, New York City, thanks to introductions by Margaret Naumburg and Professor Wendell Bush. He began teaching the philosopher and educationalist Professor John Dewey in 1915 and they began a long-standing professional relationship. Other faculty who took lessons with Alexander included Professors Wesley Mitchell, Richard Hodge and the historian James Harvey Robinson. In 1919 the New School for Social Research was established in Chelsea, New York City, and Alexander taught some of its founders including Mitchell, Dewey and the philosopher Horace Kallen. ${ }^{6}$ James Harvey 
Robinson, who had resigned from Columbia, was its first director. Alexander's work was publicly supported by these Columbia/New School radicals. ${ }^{7}$ Alexander's 1918 edition of Man's Supreme Inheritance included an introductory word by Dewey who also wrote the introduction to his 1923 book. His American reviews included those by Hodge in The New York Times (1918), Kallen in The Dial (1918) and Robinson in the Atlantic Monthly (1919). There was also a defence of Alexander by Dewey following Randolph Bourne's critical review in The New Republic (1918). ${ }^{8}$ His 1923 book, Constructive Conscious Control of the Individual, was roundly criticized in a review in the journal where Todd was published in 1920 and 1921, the Boston Medical and Surgical Journal (Anon 1924: 651), followed by a robust defence by Peter MacDonald (1924: 1098-100).

John Dewey's position at Columbia included teaching at its Teachers College. Whilst Todd was teaching in New York, she became a mature student at Teachers College, encouraged by and under the tutelage of Dr Jesse Feiring Williams, Head of Physical Education (Matt 1973: 9). Williams' view of physical education was an enlightened one, following Dewey. He cited Todd's first (1920) paper in his Principles of Physical Education (Williams 1927: 293) Todd graduated with a B.Sc. in 1927 and was employed as a lecturer in Basic Principles of Posture. She published her Teachers College syllabus privately as The Balancing of Forces in the Human Being in 1929. In 1931 she resigned from Teachers College and taught for one year at the New School for Social Research. According to Pamela Matt (1973: 10), Todd began teaching James Harvey Robinson whilst at Teachers College. Matt suggests that Robinson and Dewey debated the respective approaches of Alexander and Todd: 
The university work exposed Todd to a wide variety of students, with academic as well as personal interest in the field. Todd's classes were popular and her ideas about imagery were quite controversial. Eventually, a series of debates took place at Columbia between John Dewey, a devoté [sic] of the Alexander Technique, and James Harvey Robinson, a prominent professor of history, who studied with Todd. Most of the discussion focused on Todd's use of visualization as a corrective method. (Matt 1993: 19)

Todd dedicated her final book The Hidden You to Robinson, eighteen years after his death (1953:

7). There is no direct evidence, at present, to substantiate the suggested discussions about Alexander and Todd. However, Kallen, member of the New School Faculty, makes an interesting retrospective observation about Dewey and Alexander:

He [Alexander] said that everybody had developed bad postural habits, that posture irradiated a body's feelings and thinking, that therefore, if you could establish correct posture, you could correct everything posture involves, it was not only a universal constant, but a scheme of universal salvation.

Dewey didn't take to the salvation, but he did get something out of the physiology, as applied later, say, in Mabel Todd's The Thinking Body, and implied in Walter Cannon's The Wisdom of the Body. (Kallen in Lamont 1959: 28)

This passage is interesting for a number of reasons. First, it makes a connection between Alexander and Todd. Second, Kallen is referring to Alexander's 'universal constant', the term he employed in his last book to talk about his technique (1941). Third, his interpretation of Alexander reads more like Todd herself. In the first sentence, he attributes 'posture irradiated a 
body's feelings and thinking' to Alexander. Todd herself said in the opening chapter of The Thinking Body, referring to 'bodily attitudes', that 'we sit and walk as we think [...]. For every thought supported by feeling, there is a muscle change' ([1937] 1968: 1). There seems to be a proximity of interpretations of Todd's and Alexander's work by others, as well as proximity geographically in the late 1920 s and early 1930 s. $^{9}$

Alexander and Todd had both published new books in the 1930s. Todd's work is best known by her 1937 book The Thinking Body, published when she was teaching privately in New York. Alexander's account of the development of his technique, The Use of the Self, came out in 1932, just after he had established his first training course in London, with another extensive introduction by John Dewey. It is at this time that he began referring specifically to his technique, for instance, in his 1935 pamphlet advertising a 'New Technique employed in acquiring an improved use of the self while learning and learning to do' (Alexander 1935).

Neither Alexander nor Todd had much direct involvement with dance. They did not associate with dancers in the way they did with academics, medical practitioners and, in Alexander's case, actors. Indeed, Alexander is critical of one form of dance education in schools that he had encountered (1918b: 127). The recognition of the relevance of their work to dance did not come until much later. However, the milieus in which they worked in America in the period 1914-1933 were resonant with American Delsartism, natural dancing and the emergence of what became known as modern dance, as characterized by John Martin ([1933] 1965), in both New York and Boston. ${ }^{10}$ This was an interesting time. There was proximity between their 
respective practices and the practice of dance and dance education in New York City in particular.

The situation of dance education at Columbia University, New York City, during this period is an interesting one. Gertrude Colby taught natural dancing for the physical education curriculum at Speyer College from 1913 to 1916 and then from 1916 at Teachers College through to the 1930s. She was one of many proponents of natural dancing at that time and developed her own individual approach within an educational setting. In one of her books she gives an idea of her practice: 'Our purpose in developing Natural Dancing has been to carry on the rhythms of childhood to a higher form of the art of dancing - "the only art in which we ourselves are the stuff"'. Her work at Teachers College clearly had an impact on Williams, the Head of Physical Education, who cites her ideas of natural dancing and acknowledges her contribution in his Principles of Physical Education (1927: 262). Williams also contributed the foreword to Colby's Natural Rhythms and Dances a book that, he said, 'is reflecting in Physical Education a new spirit of the times' (Colby 1922: 5). Interestingly, the lasting impact of Columbia University on US dance education can be attributed not only to Colby, but also to John Dewey. Janice Ross makes a substantial case in her biography of Margaret H'Doubler for the lasting influence of Dewey's educational philosophy. H'Doubler established the first US dance degree programme at University of Wisconsin in 1926, where she promoted a progressive view of dance education. She placed great emphasis on the importance of the practice of dancing and its place in education in her book The Dance and its Place in Education (H'Doubler 1925): 
The type of dance, then, is educational which promotes the growth of the individual, which stimulates him to creative thought and activity, and which aims to give him the mental, physical, and spiritual poise which will enable him 'to appreciate and meet the demands of life effectively'. It is in its broadest sense, therefore, that the word dancing is here used. (H'Doubler 1925: 34)

Ross places great emphasis on H'Doubler's encounter with Dewey as a graduate student in 1916-1917. She also points to the fact that Dewey was being taught by Alexander at this time (Ross 2000). Victoria Door (2009) has argued convincingly that Dewey's idea of embodied reflection owes much to his work with Alexander. H'Doubler includes extensive bibliographies in her first (1921) and second (1925) books on dance education: it is notable that Alexander's second American edition of Man's Supreme Inheritance (1918) is included in both. It could be argued that Todd's most immediate influence on dance education is through the development of her work by Lulu Sweigard. Lulu Sweigard studied with Todd at Teachers College, University of Columbia and conducted her first unpublished research there, under Todd's supervision, in 1929/1931 (Matt 1973). In the late 1930s she completed her doctoral research at New York University (Popken 1978: 44). She began teaching her new approach to movement education, which drew on Todd's original work, and introduced it into the curriculum at the Juilliard School in New York City in 1956 (Ideokinesis.com 2011).

The New School for Social Research, where Todd was teaching in 1931 at its West 12th Street New York City premises, was also important for the development of modern dance. Doris Humphrey joined the Faculty in 1931, followed by John Martin, the writer and critic. It was in 1931-1932 that Martin gave the series of lectures that attempted to define the new dance that 
was emerging, later collected as The Modern Dance of 1933. ${ }^{11}$ It was Martin, in 1936, who made a connection between Todd's ideas and dance, saying that Humphrey 'for the formulation of something of her theory of technique [...] has expressed indebtedness to the "bodily engineering" of Mabel Elsworth Todd' (1936: 225). ${ }^{12}$ This appears to be the first direct reference to Todd's work by a modern dancer, and appears before the publication of her bestknown book ([1937] 1968).

Most accounts have brought Todd and Alexander together by virtue of developments of their work practiced in dance education in the last four decades of the twentieth century. Most of these developments occurred some three decades after the period under study here. Despite considerable detailed research, no evidence has yet been uncovered to show that Alexander and Todd actually met. However, I contend that the geographical and social proximities that I have shown make a relevant case, historically, for looking at proximities in their work and the way it was received.

\section{Conceptual proximities}

The period in which Alexander and Todd developed their techniques saw many attempts from many perspectives to reconsider how people function in the world. ${ }^{13}$ In the late nineteenth and early twentieth centuries, the term psycho-physical was one important indicator of these new approaches. The more recent term somatics was popularized by Hanna in 1970 in Bodies in Revolt and then from 1977 in his journal Somatics; the term itself, and the way certain people's work has been associated with it, is a recent development. The term psycho-physical has recently 
gained some currency again, particularly in the field of actor training (Zarrilli 2009).${ }^{14}$ Because Eddy (2009) suggests a developmental connection between the pioneers, including Alexander and Todd, and the idea of somatics, my idea is to look very closely at their use of psychophysical in its time.

The term psycho-physical entered the English language in the nineteenth century and was current in the period during which Alexander and Todd developed their techniques. The etymology of the term (Oxford English Dictionary 2011) shows that psycho-physical first appeared in English in Lloyd's 1847 translation of von Feuchtersleben's term psychisch-physisch from the German edition of Principles of Medical Psychology when he says that 'habit, likewise, greatly modifies the psycho-physical character; it is chiefly induced by education and mode of life' (1847: 151). In the latter half of the nineteenth century it was employed as a way of describing states or activities where the author wished to emphasize an interconnected relationship between body and mind. Fechner established a scientific basis for such study in 1860 in Elemente der Psychophysik. William MacDougall, in his lecture 'Psycho-physical method', translates Fechner:

By psycho-physics is to be understood an exact study of the functional relations, or relations of dependence, between body and soul, or, in more general terms, between the bodily and the mental, the physical and the psychical worlds. (Fechner cited in MacDougall 1906: 115)

It was during the same period that the compound noun 'body-mind' began to be used in a way similar to that of psycho-physical. G. H. Lewes had used the term body-mind in 1877 in Physical Basis of Mind, where he says, 'We know ourselves as Body-Mind; we do not know 
ourselves as Body and Mind, if by that be meant two coexistent independent Existents' (1877: $350)$.

There seem to have been a number of exercise systems devised that stressed the psychophysical. Some of these had their origin in Delsarte's system of expression. Most notable amongst these is that of the American Genevieve Stebbins. Stebbins wrote specifically about psycho-physical culture, and how her work differed from other proponents. In Dynamic Breathing and Harmonic Gymnastics (1892) she spends a chapter detailing her idea of "psychophysical culture', stressing the relationship between the body, brain and soul, and distancing herself from her competitors:

By the term psycho- physical culture we mean a completely rounded system for the development of body, brain and soul; a system of training which shall bring this grand trinity of the human microcosm into one continuous, interacting unison, so that nothing shall be useless, nothing thoughtless, and, consequently, nothing that is vital wasted. We say this much because all this is, unfortunately, the case with most of the popular systems of aesthetic and physical culture now before the world. There are books written and published by the score professing to elucidate this psycho-physical evolution. But the terms 'psycho' and 'psychic' are all that we can find in them, the writers thereof apparently knowing nothing, not even the merest elements, of psychology, psychic research, or of - 'those ethereal, imponderable elements which constitute the real powers by which the various functions of the soul become manifest'. (Stebbins 1892: 57) 
Those competitors would have included the Thomas sisters, who taught at their Conservatory of Thomas Psycho-Physical Culture in New York City from 1876. This was, as Julie Thomas's New York Times obituary reported (Anon 1890), where young ladies went to be taught the ways of health and physical perfection. It was, in short, part of the much wider movement of physical culture for women at that time in the United States and the United Kingdom and its use persisted until the Second World War (see Sanford (1938), for instance).

During this period the pioneers of dance and dance education did not use the term psycho-physical, as far as I can ascertain from an extensive survey of the literature. Neither was body-mind employed, although Laban did use 'body-mind' in his English talks and correspondence of 1939 (Huxley 2010). Of course, as Eddy acknowledges, Bartenieff, one of her 'pioneers', developed her ideas from Laban.

I will give a brief overview of Alexander's and Todd's own employment of psychophysical, as a prelude to a more detailed examination. Alexander first uses the term psychophysical in 1910 in the first edition of Man's Supreme Inheritance, again in his short 1912 book, and extensively in the second edition of Man's Supreme Inheritance (1918) - the one that attracted all the attention in the United States. His next book, Constructive Conscious Control of the Individual (1923), goes into great detail and includes a definition of what he means by psycho-physical. His 1932 account of how he developed his technique, The Use of the Self, begins with an explanation of how he thinks of body and mind, with reference to psychophysical. His final book, The Universal Constant in Living (1941), makes copious use of the term, beginning with a recapitulation of his 1923 definition. Todd does not use psycho-physical 
in her two early articles for the Boston Medical and Surgical Journal (1920, 1921), but introduces it in her first book of 1929, where one of her seven chapters is titled 'The psychophysical reactions of the human substance' (1929: 8-19). In the later account of The Thinking Body (1937), Todd considers posture from a number of points of view and talks about the 'psychophysical basis of posture' ([1937] 1968: 23).

Both Alexander and Todd use 'psycho-physical' as part of their explanations of how they conceive of the person for whom their technique is intended. Both wrote after a number of years in their respective practices. Alexander writes directly about his own experience and of his experience working with pupils. Todd addresses a student readership in the first instance, and then a general reader by reference to general examples. Both have something to say that sets their work apart from previous practitioners of psycho-physical culture, such as Stebbins and Thomas, and this is what I will now consider. Todd begins The Thinking Body by saying: We sit and walk as we think, watch any man as he walks down the avenue, and you can determine his status in life [...] Living, the whole body carries its meaning and tells its own story, standing, walking, awake or asleep. It pulls all the life up into the face of the philosopher, and sends it all down into the legs of the dancer. ([1937] 1968: 1)

She stresses the need to consider the 'whole' and to see the 'individual as a totality' (Todd [1937] 1968: 3). In talking about the psychophysical basis of posture she says that 'we perceive the individual as a whole rather than as a collection of parts' (Todd [1937] 1968: 24). In talking about the totality of the human being she puts this as follows: 'the individual is a totality and cannot be segregated as to intellect, motor and social factors' (Todd [1937] 1968: 2-3). What 
marks out her approach to posture, and distinguishes it from late nineteenth-century body culture is her eschewal of an exercise regime:

My purpose is to offer a procedure of thinking rather than a new type of exercise. Above all I wish to emphasize what seems to me an unavoidable conclusion in any study of posture - that it must be approached through an application of psychological and mechanical principles. (Todd 1929, foreword)

That is to say, that looking at posture from a psycho-physical point of view necessitates an approach where thinking is a prerequisite for bodily changes, and hence The Thinking Body.

Alexander explicitly distanced himself from systems of physical culture, saying that 'the whole theory upon which the present "physical-culture" school is based is but another aspect of that reversion to nature which we have stigmatized as a form of atavism' (1918a, 1918b: 14). He was clear that his technique was not based on exercises (Alexander 1923). His exposition, and use of psycho-physical, develops considerably during the course of his writings from 1910 to 1918. In 1923, in Constructive Conscious Control of the Individual, Alexander goes into detail to define how he uses psycho-physical as a way of describing the 'human organism' and its activities in a way that emphasizes the impossibility of separating the 'mental' and 'physical'.

At this juncture I wish to make clear the sense in which I use the word psycho-physical. The term psycho-physical is used both here and throughout my works to indicate the impossibility of separating 'physical' and 'mental' operations in our conception of the working of the human organism. As I wrote in Man's Supreme Inheritance, 'In my 
opinion the two must be considered entirely interdependent, and even more closely knit than is implied by such a phrase'. Hence I use the term psycho-physical activity to indicate all human manifestations, and psycho-physical mechanism to indicate the instrument, which makes these manifestations possible. (Alexander 1923:5)

Later, in 1932, in The Use of the Self, Alexander says that whilst he had begun his explorations with the idea that the mind and body could be thought of separately:

My practical experience, however, led me to abandon this point of view and readers of my books will be aware that the technique described in them is based on the opposite conception, namely that it is impossible to separate 'mental' and 'physical' processes in any form of human activity. (1932: 3)

He goes on to describe a practical technique in a way that avoids talking about the mental or the physical, or the body, as discrete, separate entities. He returns to 'psycho-physical' in his last book of 1941 with an extended recapitulation of his definition of 1923, where he stresses 'psycho-physical unity', a term particular to Alexander (1941: 5).

\section{Significant conceptual changes in the 1920s and 1930s}

It is notable that three of the New York academic circle associated with Alexander and Todd all developed a new view of the psycho-physical or body-mind during this period. They are Dewey, the philosopher and educationalist; Robinson, the historian; and Williams, the physical educationalist. Williams associated with Dewey and then Todd, Dewey with Alexander and Robinson; Robinson with Dewey, Alexander and Todd. As mentioned previously, it has 
been suggested that Robinson and Dewey debated the different approaches of Alexander and Todd (although there is no extant published evidence of such an encounter). In other words, there is a small group of people within the wider academic milieus identified earlier who were discussing a particular idea at the same time as Alexander and Todd. This is not to suggest that there is a direct causal relationship at work here. However, there was certainly a very particular intellectual climate in New York that enabled certain developments to become explicit in a particular way. Dewey captures the idea very well in a biography when considering this period:

There are no ideas which are original in substance, but a common substance is given a new expression when it operates through the medium of individual temperament and the peculiar, unique, incidents of an individual way. (Dewey cited in Dewey 1939: 44)

I am going to consider Williams first and then Robinson and will finally return to Dewey.

Williams, it has been noted, had a 'progressive view of physical education', as shown, most obviously, in his The Principles of Physical Education (1927), where he cites Todd (1920). Indeed, he became renowned for an approach typified as 'education through the physical', which actually challenged the dualistic approach implied by the expression (Kretchmar and Geber 1983). In his book he approaches physical education very broadly, drawing not only on anatomy and physiology, but also the philosophy of William James and John Dewey. He had a background in anatomy and physiology, and the second edition of $A$ Text-book of Anatomy and Physiology was included in Todd's booklist for her 1927 syllabus based on the teaching of posture that she was undertaking for him. Whilst he touches on the question of the education of both body and mind in 1927, it is three years later, in 1930, that he makes his most adventurous 
statement. A brief article for The Journal of Higher Education is titled 'Education through the physical'. It is the article's subtitle that indicates that Williams was taking a new approach - 'A new view of physical education based upon the biologic unity of mind and body' (1930). In this he proposes that:

Modern physical education with its emphasis upon education through the physical is based upon the biologic unity of mind and body. This view sees life as a totality [...] Deification of only the physical, or the mental, or the spiritual leads to disaster. (Williams 1930: 279)

In this, his views show a remarkable proximity to those of both Todd and Alexander of the same period, and indeed those of John Dewey.

James Harvey Robinson became a pupil of Alexander after Dewey had begun lessons and contributed a substantial review of Man's Supreme Inheritance, 'The philosopher's stone', to the Atlantic Monthly, published in Boston and New York (Robinson 1919). This review is of Alexander's book but, more broadly, of his practice as experienced by Robinson in lessons. He talks of both the psycho-physical and body and mind in trying to evaluate Alexander's work with reference to posture, saying that 'we should recognize that mind and body are really two phases of the same thing, so intimate and constant is their interaction' (Robinson 1919: 480).

Robinson maintains a similar view of mind and body in his 1921 book The Mind in the Making proposing that "what we think of as "mind" is so intimately associated with what we call "body" 
that we are coming to realize that the one cannot be understood without the other' (1921: 34). It is The Mind in the Making that Todd includes on her reading list in her 1927 book, alone alongside all the texts on anatomy, physiology and engineering, and it is Robinson who she dedicates her final 1953 book to, as 'a devoted adherent to the philosophy expressed in this book' (Todd 1953, frontis). Although Todd cites Robinson, he himself makes no reference to her in his few later writings, and she is not mentioned in Hendricks' (1946) biography, although this is primarily about him as a teacher of history.

Dewey, as we have seen, became a pupil of Alexander in 1915. It is interesting to see how his ideas develop over the following twenty years. Dewey wrote an introduction to the second, American, edition of Man's Supreme Inheritance published by Dutton (1918b: xiii-xvii). He supports Alexander's approach and his criticism of 'physical culture methods' and stresses the need for balance and a reflective approach (Dewey 1918: xiv). He does not make an explicit statement about the psycho-physical, but, as we have seen, Alexander's own use of the term in his earliest book is limited. Whereas Robinson does not refer directly to Alexander after 1919, Dewey continued his relationship with him, and with his brother A. R. Alexander, until 1941. Their friendship has been referred to at some length, and its importance is a matter of some dispute. Jones ([1976] 1997) gives a detailed and considered account of its significance and draws on his own discussions with Dewey. He quotes Dewey as having said of Alexander's technique that 'he had taken it first because it provided a demonstration of the unity of mind and body' (Jones [1976] 1997: 96-97). This view is echoed in the 1939 biography where he is quoted as saying: 
My theories of mind-body, of the coordination [sic] of the active elements of the self and of the place of ideas in inhibition and control of overt action required contact with the work of F.M. Alexander and in later years his brother, A.R. to transform them into realities. (Dewey cited in Dewey 1939: 44-45).

Alexander's ideas are referred to by Dewey in Human Nature and Conduct (1922) and Experience and Nature (1925). His next direct commentary on Alexander's work was an introduction to Constructive Conscious Control of the Individual (1923). According to Jones ([1976] 1997), this was at a time when Alexander was teaching in Boston and Dewey travelled up from New York for lessons and to discuss the draft ([1976] 1997: 37). In this extensive introduction to the book where Alexander defines his understanding of the psycho-physical (Dewey 1923: 5-6), Dewey talks of how our habits need re-education because 'that which is familiar to our sense of ourselves and of our acts can only be a reflection of the bad-psychophysical habits that are operating within us' (Dewey 1923: xxx). He refers to years of study with Alexander and how his approach is different. He goes on to distance Alexander's method from others':

In some plans there has been a direct appeal to 'consciousness' (which merely registers bad conditions); in some, this consciousness has been neglected entirely and dependence placed instead upon bodily exercises, rectifications of posture, etc. But Mr. Alexander has found a method for detecting precisely the correlations between these two members, physical-mental, of the same whole, and for creating a new sensory consciousness of new attitudes and habits. (Dewey 1923: xxxi-xxxii) 
Dewey expands on his direct experience of Alexander's technique in an introduction to The Use of the Self (1932) where he couches this in terms of the psycho-physical: 'and so I verified in personal experience all that Mr. Alexander says about the unity of the physical and the psychical in the psycho-physical' (Dewey 1932: xvii).

He goes on to give a personal example of what this means:

In re-affirming my conviction as to the scientific character of Mr. Alexander's discoveries and technique, I do so then not as one who has experienced a 'cure,' but as one who has brought whatever intellectual capacity he has to the study of a problem. In the study, I found the things that I had 'known' - in the sense of theoretical belief - in philosophy and psychology, changed into vital experiences which gave a new meaning to knowledge of them. (Dewey 1932: xvii-xviii)

In a sophisticated address to the New York Academy of Medicine in 1927 Dewey spoke about 'Body and Mind' and the problems that arise in trying to grapple with the idea of body-mind. I suggest that although his account was published (1928) over 80 years ago, the problems that it raises are still with us when talking about the psycho-physical, or body-mind, or 'the body' in terms of twenty-first-century dance practices, and especially in terms of those that might be labelled 'somatic'. He says:

We have no word by which to name mind-body in a unified wholeness of operaton [sic]. For if we said 'human life' few would recognize that it is precisely the unity of mind and 
body in action to which we were referring. Consequently when we discuss the matter, when we talk of the relations of mind and body and endeavor to establish their unity in human conduct, we still speak of body and mind and thus unconsciously perpetuate the very division we are striving to deny. (Dewey 1928: 6)

Dewey makes a good point. To talk of 'human life' or the human being as a way of identifying a 'unified wholeness of operation' is neither obvious, nor specific enough. However, in dance education, we do have a very particular term - dancers, who some of us think of as people engaged in a unified wholeness of operation.

This examination of Alexander's and Todd's work has shown considerable geographical and historical proximities. During the period examined, there was a conceptual milieu within which a range of new ideas about the human being was being developed. It can be seen that both Alexander and Todd developed their ideas in proximity with practitioners and writers in a range of disciplines. A historical rereading of Alexander and Todd, and their contemporaries, especially Dewey, poses an interesting challenge for us as educators. When we look at dancers and students who are dancers, how do we conceive of them, and how do we talk of them and what they are engaging in? Does our language betray the persistent dualistic thinking that we strive to get beyond, or do we champion dancers and dancing as exemplars of new ways of thinking of the self?

\section{Acknowledgement}


With my sincere thanks to Brian Door.

\section{References}

Alexander, F. M. (1906), Introduction to a New Method of Respiratory Vocal Re-Education, London: Baillière.

(1910), Man's Supreme Inheritance, London: Methuen.

(1912), Conscious Control in Relation to Human Evolution in Civilization, London: Methuen.

(1918a), Man's Supreme Inheritance: Conscious Guidance and Control in Relation to Human Evolution in Civilization, revised 2nd ed., London: Methuen.

(1918b), Man's Supreme Inheritance: Conscious Guidance and Control in Relation to Human Evolution in Civilization, 2nd ed., New York: E. P. Dutton.

(1923), Constructive Conscious Control of the Individual, New York: E. P. Dutton.

(1932), The Use of the Self: Its Conscious Direction in Relation to Diagnosis, Functioning and the Control of Reaction, London: Methuen.

(1935), A New Technique Employed in Acquiring an Improved Use of the Self while Learning and 
Learning to Do, London: CA: Watts and The F. Matthias Alexander Trust Fund. (1941), The Universal Constant in Living, New York: Dutton. (1995), Articles and Lectures, London: Mouritz. (1996), Man's Supreme Inheritance, 6th ed., London: Mouritz. (2000), The Universal Constant in Living, 4th ed., London: Mouritz. (2004), Constructive Conscious Control of the Individual, 3rd ed., London: Mouritz.

Anon (1890), 'Miss Julia Thomas: Something about her interesting life's work', New York Times, 5 January.

(1924), 'Constructive conscious control of the individual: Review', Boston Medical and Surgical Journal, 191: 14, 2 October, p. 651.

Bales, M. and Nettl-Fiol, R. (eds) (2008), The Body Eclectic: Evolving Practices in Dance Training, Chicago: University of Illinois Press.

Bourne, R. (1918), 'Making over the body', The New Republic, XV, 4 May, pp. 28-29. 
Bourne, R. (1918), 'Other Messiahs', The New Republic, XV, 25 May, p. 117.

Cannon, W. B. (1932), The Wisdom of the Body, New York: W. W. Norton.

Colby, G. R. (1922), Natural Rhythms and Dances, New York: A. S. Barnes.

Dewey, J. (1918), 'Introductory word', in F. M. Alexander (ed.), Man's Supreme Inheritance: Conscious Guidance and Control in Relation to Human Evolution in Civilization, New York: E. P. Dutton, pp. xiii-xvii.

([1922] 1938), Human Nature and Conduct: An introduction to Social Psychology, New York: Henry Holt.

(1923), 'Introduction', in F. M. Alexander (ed.), Constructive Conscious Control of the Individual, New York: E. P. Dutton, pp. xxi-xxxiii.

(1925), Experience and Nature, Chicago: Open Court.

(1928), 'Body and mind', Bulletin of the New York Academy of Medicine. IV: 1, pp. 3-9.

(1932), 'Introduction', in F. M. Alexander (ed.), The Use of the Self: Its Conscious Direction in Relation to Diagnosis, Functioning and the Control of Reaction, New York: E. P. Dutton, pp. xiii-xix. 
(1939), 'Biography of John Dewey', in P. A. Schilpp (ed.), The Philosophy of John Dewey, 1st ed., New York: Tudor.pp. 1-45.

Door, V. (2009), 'Postural configuration as a missing element in reflective epistemology', in T. Randall (ed.), CORD Special Conference. Global Perspectives on Dance Pedagogy: Research and Practice, De Montfort University, Leicester, UK: CORD. pp. 139-142.

Eddy, M. (2009), 'A brief history of somatic practices and dance: historical development of the field of somatic education and its relationship to dance,' Journal of Dance and Somatic Practices, 1:1, pp. 5-27.

Emerson, C. W. (c. 1891), Physical Culture of the Emerson College of Oratory, 7th ed., Boston: Emerson College of Oratory.

Evans, J. A. (2001), Frederick Matthias Alexander: A Family History, Chichester: Phillimore.

Fechner, G. T. (1860), Elemente der Psychophysik, Leipzig: Breitkopf and Härtel.

Feuchtersleben, Baron E. von (1847), B. G. Babington (revised and ed.), Chapter 3 Physiology, The Principles of Medical Psychology (trans. H. Evans Lloyd), London: Sydenham Society. pp. 76-172. 
Fitt, S. A. ([1988] 1996), Dance Kinesiology, 2nd ed., New York: Schirmer.

H'Doubler, M. N. (1921), A Manual of Dancing: Suggestions and Bibliography for the Teacher of Dancing, Madison, WI: Privately published.

(1925), The Dance and Its Place in Education, New York: Harcourt, Brace and Company.

Hanna, T. (1970), Bodies in Revolt: A Primer in Somatic Thinking, 1st ed., New York: Holt, Rhinehart and Winston.

Hendricks, L. K. (1946), James Harvey Robinson - Teacher of History, New York: King's Crown Press.

Hodge, R. M. (1918), 'What is Man's Supreme Inheritance', New York Times Book Review, 5 May, p. 211.

Huxley, M. (2010), 'Movement concerns the whole man', in V. Preston-Dunlop and L. A. Sayers (eds), The Dynamic Body in Space: Exploring and Developing Rudolf Laban's Ideas for the 21st Century, Alton: Dance Books. pp. 95-103.

Huxley, M. and Burt, R. (2011), 'Ideas of nature, the natural and the modern in early twentiethcentury dance discourse', in A. Carter and R. Fensham (eds), Dancing naturally: Nature, Neo-Classicism and Modernity in Early Twentieth Century Dance, Basingstoke: Palgrave. 
pp. 31-42.

Ideokinesis.com (2011), 'The pioneers: Lulu Sweigard', www.ideokinesis.com/pioneers/sweigard/sweigard.htm. Accessed 10 November 2011.

Johnson, D. H. (ed.) (1995), Bone, Breath and Gesture: Practices of Embodiment, Berkeley, CA: North Atlantic Books.

Jones, F. P. ([1976] 1997), Freedom to Change: The Development and Science of the Alexander Technique, 3rd ed., London: Mouritz.

Kallen, H. M. (1918), 'Conscious control of the body', The Dial, 6 June, pp. 533-34.

Kretchmar, R. S. and Gerber, E. W. (1983), 'Jesse Feiring Williams: A philosophical and historical review', Journal of Physical Education, Recreation \& Dance, 54:1, pp. 16-17, $19-20$.

Kriegsman, S. A. (1981), Modern Dance in America--the Bennington Years, Boston, Mass.: G.K. Hall.

Lamont, C. (1959), Dialogue on John Dewey, New York: Horizon.

Lewes, G. H. (1877), The Physical Basis of Mind, Boston: James R Osgood. 
MacDonald, P. (1924), 'Criticism of a book review, Boston Medical and Surgical Journal, 191, 23, 4 December, pp. 1099-1100.

Mackenzie, S. W. C. ([1918] 1930), The Action of Muscles, Including Muscle Rest and Muscle Re-Education, 2nd ed., London: H. K. Lewis.

Martin, J. ([1933] 1965), The Modern Dance, New York: Dance Horizons. (1936), America Dancing, New York: Dodge.

Matt, P. H. (1973), 'Mabel Elsworth Todd and Barbara Clark - principles, practices, and the import for dance', unpublished M.A. thesis, Urbana, Illinois: University of Illinois at Urbana-Champaign.

(1993), A Kinesthetic Legacy: The Life and Works of Barbara Clark, Tempe, AZ: CMT Press.

(1996), 'The nature of Ideokinesis and its value for dancers', in S. A. Fitt (ed.), Dance Kinesiology, 2nd ed., New York: Schirmer, pp. 335-41.

(2011), 'Mabel Elsworth Todd', Ideokinesis, http://www.ideokinesis.com/ Accessed 16 June 2011. 
Maynard, O. (1964), American Modern Dancers: The Pioneers, Boston: Little, Brown.

McDougall, W. (1906), 'Psycho-physical method', in T. B. Strong (ed.), Lectures on the Method of Science, Oxford: Clarendon Press, pp. 110-31.

McDougall, W. (1906), 'Psycho-physical method', in T. B. Strong (ed.), Lectures on the Method of Science, London: Oxford University Press. pp. 110-131

Oxford English Dictionary (2011), 3rd online ed., Oxford: Oxford University Press, www.oed.com/view/Entry/153928?redirectedFrom=psycho-physical\#eid. Accessed 10 November 2011.

Popken, F. (1978), 'Efficiency in Movement through Ideokinesis (The Sweigard Method)', CORD Research Annual, XI, 41-46.

Robinson, J. H. (1912), The New History, New York: Macmillan. (1919), ‘The philosopher's stone', Atlantic Monthly, February, pp. 474-81. (1921), The Mind in the Making: The Relation of Intelligence to Social Reform, New York: Harper. 
(1923), The Humanizing of Knowledge, New York: George H Doran.

Ross, J. (2000), Moving Lessons: Margaret H'Doubler and the Beginning of Dance in American Education, Madison: University of Wisconsin.

Rutkoff, P. M. and Scott, W. B. (eds) (1986), New School: A History of the New School for Social Research, New York: Simon and Schuster.

Sanford, J. (1938), Psycho-Physical Culture: Nine Lessons on the Power of Breathing, London: C Arthur Pearson.

Staring, J. (1994), F. Matthias Alexander, Randolph Bourne and John Dewey: Playing Detective with Man's Supreme Inheritance, Nijmegen: Privately published.

(2005), Frederick Matthias Alexander: The Origins and History of the Alexander Technique, Nijmegen: Integraal.

Stebbins, G. (1892), Dynamic Breathing and Harmonic Gymnastics: A Complete System of Psychical, Aesthetic and Physical Culture, 2nd ed., New York: E.S. Werner.

Stodelle, E. (1978), The Dance Technique of Doris Humphrey and Its Creative Potential, Princeton: Princeton Book Company. 
Stout, G. F. (1931), Mind and Matter, Cambridge: Cambridge University Press.

Todd, M. E. (1920), 'Principles of posture', Boston Medical \& Surgical Journal, clxxxii:26, 24 June, pp. 645-49.

(1921), 'Principles of posture, with special reference to the mechanics of the hip joint', Boston Medical \& Surgical Journal, clxxxiv:25, 23 June, pp. 667-73.

(1929), The Balancing of Forces in the Human Being: It's Application to Postural Patterns, New York: Privately Published.

(1931), 'Our strains and tensions', Progressive Education, VII, March, pp. 242-46.

(1934), The First Principles of Body Balance, New York: Mabel Elsworth Todd Studios.

([1937] 1968), The Thinking Body: A Study of the Balancing Forces of Dynamic Man, New York: Dance Horizons.

(1953), The Hidden You, New York: Exposition.

(1977), Early Writings 1920-1934, New York: Dance Horizons. 
Weber, J. (2009), The Evolution of Aesthetic and Expressive Dance in Boston, Amherst: Cambria Press.

Whyman, R. ([2008] 2011), The Stanislavsky System of Acting, Cambridge: Cambridge University Press.

Williams, J. F. (1927), The Principles of Physical Education, Philadelphia: WB Saunders.

(1930), 'Education through the physical', The Journal of Higher Education, 1:5, pp. 27982.

Zarrilli, P. B. (2009), Psychophysical Acting: An Intercultural Approach after Stanislavski, London: Routledge.

\section{Contributor details}

Michael Huxley is a researcher and teacher at De Montfort University, UK. He has been published in a number of books including, most recently, with Ramsay Burt, in Carter, A. and Fensham, R. (eds) (2011), Dancing Naturally: Nature, Neo-Classicism and Modernity in Early Twentieth Century Dance. He has written for various dance periodicals including New Dance, and most recently, Research in Dance Education and Discourses in Dance. His published research has been on early European modern dance, British new dance and dance history. He was a board 
member of the Congress on Research in Dance (CORD) for ten years and Chair of the Editorial Board for Dance Research Journal. He was Senior Academic Adviser Dance and Chair of the Advisory Board for the HEA Subject Centre PALATINE. He was Project Leader for the Centre

for Excellence in Performance Arts (CEPA 2005-2010) at DMU. He qualified as a teacher of the Alexander Technique in 2004 with the Professional Association of Alexander Teachers. He is currently working on research projects on the learning and teaching of dance history, early modern dance and, with Jayne Stevens, the work of the Akram Khan Company.

Contact:

Michael Huxley, School of Arts, Faculty of Art, Design and Humanities, De Montfort University, The Gateway, Leicester LE1 9BH, UK.

E-mail:mrhuxley@dmu.ac.uk

Figure 1: Photograph of F.M. Alexander in 1910 (C) 2010, The Society of Teachers of the Alexander Technique, London.

Figure 2: Mabel Elsworth Todd as a student at Emerson College in 1908, from The Emersonian (by permission of Emerson College Archives). 
Figure 3: Area around lower Central Park, Manhattan, 1920, from 'Chief points of interest in upper Manhattan’ Automobile Blue Book, Volume 2, 1920 (with acknowledgement to University of Texas libraries).

\section{Notes}

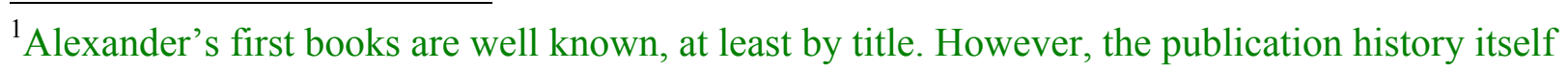
is complicated. The Mouritz editions of Man's Supreme Inheritance, Constructive Conscious Control of the Individual and The Universal Constant in Living include details of the publication of the different editions by a number of publishers. The printing history of the first book is especially interesting (Alexander 1996: 233-38). Staring (1994) devotes an entire pamphlet to the differences in the Methuen and Dutton 1918 editions in the United Kingdom and United States, respectively. Alexander's articles, with a full chronology, are collected in Alexander (1995).

2 Todd's early articles are collected in Todd (1977). Her 1920 article for the Boston Medical and Surgical Journal states that this is a 'first paper' (Todd 1920: 645).

${ }^{3}$ The idea of 'use' as a way of describing the human in activity is particular to Alexander and is encapsulated in his third book, The Use of the Self. Alexander talks about the totality of how a person engages their mechanisms in the world as their 'use' and gives an account (which is written in the period under consideration) of how this applies to both perceived mental and physical activities:
}

When I employ the word 'use', it is not in that limited sense of the use of any specific part, as, for instance, when we speak of the use of an arm or the use of a leg, but in a 
much wider and more comprehensive sense applying to the working of the organism in general. For I recognize that the use of any specific part such as the arm or leg involves of necessity bringing into action the different psycho-physical mechanisms of the organism, this concerted activity bringing about the use of the specific part. (Alexander 1932: 4).

${ }^{4}$ For instance, Todd's ideas are couched in terms of posture: Alexander avoided the word posture as far as possible in his writings and teaching. Todd's particular contribution is the employment of imagery as an imaginative aid to improvement. Alexander did not employ imagery. They had quite different ideas about 'feelings' and their reliability. Both refer extensively to the most significant physiologist of the time, Sir Charles Sherrington: Todd makes considerable direct reference to anatomy and physiology and The Thinking Body, in particular, is marked by its anatomical illustrations: Alexander's books contain no anatomical diagrams but are credited by Dewey and others as scientific in method.

${ }^{5}$ John Dewey in his introduction to Alexander's The Use of the Self draws attention to the nature of Alexander's 'discoveries', teaching and Technique (1932: xv-xvi).

${ }^{6}$ Margaret Naumburg had been a pupil of John Dewey's and went on to found the New York Walden School. Wendell T. Bush (1866-1941) was a Professor of Philosophy at Columbia; John Dewey (1859-1952) was a Professor of Philosophy at Columbia University and Teachers College; Professor Wesley Mitchell (1874-1948) was an economist; Richard M. Hodge (18641924) was Professor of English and Biblical Literature; Horace Kallen (1882-1974) taught philosophy at University of Wisconsin - Madison before becoming Professor of Philosophy at the New School for Social Research. James Harvey Robinson (1863-1936) was Professor of History at Columbia and author of The New History (1912). Jones ([1996] 1997) gives a 
substantial account of Alexander's time in New York and, especially, his time with John Dewey. There is a very good account of the history of the New School for Social Research in Rutkoff and Scott (1986). Hendricks (1946) gives a fine account of Robinson as a teacher.

${ }^{7}$ Rutkoff and Scott (1986) give a very good account of how the New School for Social Research had its beginnings in a radical climate.

${ }^{8}$ The correspondence between Bourne and Dewey over Alexander is examined in great detail by Staring (1994).

${ }^{9}$ Both Jones ([1996] 1997) for Alexander and Matt (1973) for Todd make much of the association of both figures, quite separately, with the medical faculty at Massachusetts General Hospital.

${ }^{10}$ It is interesting that Jody Weber, for instance, in her detailed account of dance in Boston of this period (2009) makes no reference at all to Todd or her Studio. She does, however, give an account of Delsartism, physical culture and even mentions Emerson College. There is a sense that Todd here, and Alexander elsewhere, has been afforded no connection with dance for the period when their practices developed.

${ }^{11}$ The 'proximities' of the modern dance pioneers find a geographical and historical focus at the Bennington Summer Schools of 1934-1938. These had been inaugurated by Martha Hill and, as Sali Ann Kriegsman points out, the summer schools 'proceeded quite naturally from Martin's pioneering series' (1981: 9) at the New School for Social Research.

${ }^{12}$ Ernestine Stodelle (1978) attributes quotations in some of Humphrey's notes on her technique to Todd (1937).

${ }^{13}$ See Huxley and Burt (2011) for an extensive account. 
${ }^{14}$ In Whyman's ([2008] 2011) account of Stanislavsky and his actor training, researched from the Russian sources, she says that Stanislavsky was discussing 'psycho-physiology' in 1908 ([2008] 2011: 247) and the psycho-physical in My Life in Art ([2008] 2011: 11) but also shows that his conception of mind-body unity was 'inconsistent' ([2008] 2011: 250-52). Zarrilli (2009: 1) says that Stanislavski was innovative in his use of the term 'psycho-physical' in the nineteenth century: his book, Psychophysical Acting: An Intercultural Approach after Stanislavski describes the training he has developed since 1976. 